\title{
Distortions to world trade: impacts on agricultural markets and farm incomes
}

Kym Anderson, Will Martin and Dominique van der Mensbrugghe

\author{
World Bank \\ 1818 H Street NW \\ Washington DC 20433 \\ kanderson@worldbank.org \\ wmartin1@worldbank.org \\ dvandermensbrugg@worldbank.org
}

World Bank Policy Research Working Paper 3736, October 2005

The Policy Research Working Paper Series disseminates the findings of work in progress to encourage the exchange of ideas about development issues. An objective of the series is to get the findings out quickly, even if the presentations are less than fully polished. The papers carry the names of the authors and should be cited accordingly. The findings, interpretations, and conclusions expressed in this paper are entirely those of the authors. They do not necessarily represent the view of the World Bank, its Executive Directors, or the countries they represent. Policy Research Working Papers are available online at http://econ.worldbank.org.

This is a product of the World Bank's pair of projects on Agricultural Trade Reform and the Doha Development Agenda and on Putting Development Back into the Doha Agenda: Poverty Impacts of a WTO Agreement. Chapters for the two books to be published in late 2005 can be downloaded at www.worldbank.org/trade/wto. The authors are grateful for helpful comments from project participants and for funding from the UK and Dutch governments. 


\begin{abstract}
This paper provides estimates of the impact that removing all merchandise trade distortions (including agricultural subsidies) would have on food and agricultural production, trade and incomes. Using the latest versions of the GTAP database and the World Bank’s LiNKAGE model of the global economy (projected to 2015), our results suggest farm employment, the real value of agricultural output and exports, the real returns to farm land and unskilled labor, and real net farm incomes would all rise substantially in developing country regions with a move to free merchandise trade, thereby alleviating rural poverty - despite the decline in international terms of trade for developing countries that are net food importers or are enjoying preferential access to agricultural markets of high-income countries.
\end{abstract}

\title{
JEL codes: C68, D58, F17, Q17
}

Key words: Trade policy reform, computable general equilibrium modeling, agricultural markets, economic welfare

\section{Contact author:}

Kym Anderson

Development Research Group

The World Bank

Mailstop MC3-303

1818 H Street NW

Washington DC 20433 USA

Phone +1 2024733387

Fax +12025221159

kanderson@worldbank.org 


\section{Distortions to world trade: impacts on agricultural markets and farm incomes}

To what extent are government trade and subsidy policies still distorting agricultural markets and farmers' incentives around the world? Nearly two decades ago a major World Bank study addressed that question for 18 developing countries (Krueger, Schiff and Valdes 1988), and found that farmers in those countries were discriminated against by their governments’ policies, albeit less so directly than indirectly (via restrictions on imports of industrial products and overvalued exchange rates). Another study at that time focused on time series data for developed and newly industrializing countries, and found a tendency for national governments to gradually change from taxing to subsidizing agricultural relative to industrial production (and from subsidizing to taxing food consumers) in the course of their economic development, and at an earlier stage the weaker an economy's comparative advantage in agriculture (Anderson and Hayami 1986).

Meanwhile the OECD Secretariat has been estimating direct producer supports by its member governments, and finds that they all support their farmers and that the aggregate degree of support is high and has not fallen over the past fifteen years (Legg 2003, OECD 2005) having risen substantially over earlier post-World War II decades when manufacturing protection rates began falling to what are now very low levels in those countries.

That is, developing countries’ policies of the past had caused international prices of farm products to be above what they otherwise would have been, while the policies of high-income countries had the opposite effect. A partial equilibrium attempt to measure the net effect of those 
policies in the 1980s suggests they almost exactly offset each other in terms of their impact on international prices of temperate foods, while more than halving the volume of international food trade (Tyers and Anderson 1992, Table 6.9). Hence developing country farmers and agricultural production at that time were clearly discriminated against by the patterns of distortions across sectors and regions.

Since the 1980s, however, a number of major policy changes have occurred. Many developing countries have been reforming their trade and subsidy regimes unilaterally; innumerable preferential trading arrangements (some reciprocal, others non-reciprocal) have been signed and have led to sub-global or discriminatory trade liberalization that may or may not have improved global welfare; the Uruguay Round of multilateral trade negotiations, begun in 1986, came to a successful conclusion in 1994 and by end-2004 the agreed reforms were fully implemented; and the World Trade Organization (WTO) came into being to replace the GATT Secretariat on 1 January 1995 and since then its membership has grown by 20 to almost 150 customs territories, with new members (especially China) committing to significant reforms as the price of admission (Crawford and Fiorentino 2005; World Bank 2002, 2004, 2005; Drabek and Bacchetta 2004).

By the mid-1990s it appeared to one group of analysts that, for the sample of fifteen developing countries they examined, the problem of an anti-agricultural bias in those countries' trade and sectoral policies had all but disappeared (Jensen, Robinson and Tarp 2002). But what about in other developing countries? And are some developing countries overshooting and adopting the potentially equally wasteful agricultural protectionist stance of more-advanced economies? 
To answer these questions requires extending the time series of estimates of distortions in the Krueger/Schiff/Valdes sample and extending the sample to a wider range of countries. That is the focus of a new research project getting under way at the World Bank. But in the meantime it is possible to answer the question in the title of the present paper using a new database for 2001. Specifically, here we address the question: What would be the consequences for agricultural markets and farm incomes if all countries were to reduce their trade distortions simultaneously (as in an ambitious WTO round), as distinct from just reducing their own distortions? ${ }^{1}$

That is, the aim of this paper is to make use of a new database and a global general equilibrium model to assess how agricultural markets and value added in agriculture would change if, over the next decade, the world were to remove all merchandise trade barriers and agricultural subsidies. While no-one anticipates such a radical reform, the analysis serves as a benchmark to suggest what is at stake in the WTO's current round of multilateral trade negotiations - as well as in further unilateral reforms. It can also give a better indication of agricultural comparative advantages around the world than is available by looking at indicators in the current distortion-ridden situation.

Specifically, we make use of the World Bank’s recursive dynamic model of the global economy known as LINKAGE (van der Mensbrugghe 2004), which has formed the basis for the World Bank’s standard decade-long projections of the global economy and of its earlier trade analysis (e.g., World Bank 2002, 2004). The distinction is made in our welfare results between

1 The Krueger, Schiff and Valdes (1988) and Jensen, Robinson and Tarp (2002) studies focused on effects of just own-country policies, the first using partial equilibrium and the second using national general equilibrium models. On the relationship between those two methodologies, see Bautista, Robinson, Wobst and Tarp (2001). 
effects of moving to free trade by developing countries versus by high-income countries, and in agriculture as compared with non-agricultural sectors. We also make use of the latest GTAP database (Version 6.05, see www.gtap.org) which has the virtue of including not only reciprocal but also non-reciprocal preferential tariffs, the latter providing low-income exporters duty-free access to protected high-income country markets. This allows us to take into account the fact that reform may cause a decline in the international terms of trade for those developing countries that are enjoying preferential access to agricultural markets of high-income countries (in addition to those that are net food importers because their comparative advantage is in other sectors such as labor-intensive manufacturing).

The paper begins with an examination of current distortions, the emphasis being mainly on import tariffs since they are later shown to be far more important than agricultural subsidies. This is followed by a description of the LINKAGE model of the global economy to be used to analyze the consequences of removing those distortions. The key results of the simulations are then presented. After discussing some qualifications, the paper concludes by highlighting the key messages and drawing out implications for developing countries in particular.

\section{Key distortions in global markets}

Border measures traditionally have been the main means by which governments distort prices in their domestic markets for products, with the price of tradables relative to nontradables affected by interventions in the market for foreign exchange, and the relative prices of the various tradables affected by trade taxes-cum-subsidies or quantitative trade restrictions. Multiple exchange rates have also altered relative prices among tradable products. Product- 
specific domestic producer or consumer subsidies have played a more limited role (because of their much greater cost to the treasury), with a few exceptions most notably in rich-country agriculture. With the freeing up of most foreign exchange markets over the past two decades, the phasing out of most export taxes, ${ }^{2}$ and the conversion of many non-tariff trade barriers into tariffs, the task of measuring the extent of distortions to goods markets is made much easier in that attention can focus on import tariffs and agricultural subsidies. In principle services trade and foreign investment distortions also could distort incentives in the agricultural and industrial sectors, but they are ignored here partly because much controversy still surrounds their measurement and how they should be modelled, and partly because they do not seem destined for major reform under the current Doha Development Agenda of multilateral trade reform by WTO members.

The latest release of the GTAP dataset, Release 6.05, includes estimates of bilateral tariffs and of domestic and export subsidies as of 2001 for 87 countries and country groups spanning the world. This is a substantial improvement over Version 5 of the GTAP dataset, which relates to 1997. The new protection data come from a joint CEPII (Paris)/ITC (Geneva) project. The product of this joint effort, known as MAcMaps, is a HS6 tariff level detailed database on bilateral protection that integrates trade preferences, specific and compound tariffs and a partial evaluation of non-tariff barriers such as tariff rate quotas (TRQs). ${ }^{3}$ The new GTAP database has lower tariffs than the previous database. This is because of the inclusion of bilateral trade preferences, as well as the major reforms between 1997 and 2001 such as continued

2 Apparently only a few minor export taxes remain - see Piermartini (2004) and also Thiele (2004).

3 More information on the MAcMaps database is available in Bouët et al. (2004) and at http://www.cepii.fr/anglaisgraph/bdd/macmap.htm. For details of its incorporation into the GTAP Version 6 dataset, see www.gtap.org. 
implementation of the Uruguay Round agreements, and China's progress towards WTO accession (which alone contributed to the ratio of global exports plus imports to GDP rising from 44 to 46 percent over those four years).

According to this dataset, the average import tariff for agriculture and food in 2001 was 16.0 percent for high-income countries and 17.7 percent for developing countries, while for manufactures other than textiles and clothing it was 8.3 percent for developing countries and just 1.3 percent for high-income countries (Table 1). The averages of course obscure large variations across countries and commodities, and are poor indicators of overall assistance to farming. For example, if high-income countries' tariffs on temperate farm products are at a near-prohibitive 100 percent, but zero on tropical products such as coffee, those countries' import-weighted average agricultural tariff could be quite low even though agricultural value added in those rich countries had been enhanced substantially. Consider also the case of a developing country with a strong agricultural comparative advantage in all but one small farming industry, and with high tariffs to stave off import competition for that industry and for all manufacturing industries. Overall agricultural value added would be depressed by that structure of protection, yet the import-weighted average tariff protection for agriculture would be high and possibly above that for manufactures. A third case is where the non-agricultural primary sector receives a similar level of import protection as the farm sector and less than the manufacturing sector, but is much more export-focused: trade reform may cause it to expand at the expense not only of manufacturing but also of farming. Hence it is not possible to say from the tariff data in Table 1 whether developing country policies have overshot in terms of moving away from an antiagricultural bias, even though the ratio of agricultural to all goods tariffs in that table is well above unity for each of the regions shown. What is needed to address that issue is a general 
equilibrium model to estimate the net effects of all sectors' distortions on agricultural markets and net farm income, to which we now turn.

\section{The global LINKAGE model for assessing sectoral and welfare effects of trade distortions}

The model used for this analysis is the World Bank's global dynamic computable general equilibrium (CGE) model, known as LiNKAGE (van der Mensbrugghe 2004). It is a relatively straightforward CGE model but with some characteristics that distinguish it from standard comparative static models such as the GTAP model (described in Hertel 1997). A key difference is that it is recursive dynamic, so while it starts with 2001 as its base year it can be solved annually through to 2015. The dynamics are driven by exogenous population and labor supply growth, savings-driven capital accumulation, and labor-augmenting technological progress as assumed for the Global Economic Prospects report in World Bank (2005). In any given year, factor stocks are fixed. Producers minimize costs subject to constant returns to scale production technology, consumers maximize utility, and all markets - including for labor - are cleared with flexible prices. There are three types of production structures. Crop sectors reflect the substitution possibilities between extensive and intensive farming; livestock sectors reflect the substitution possibilities between pasture and intensive feeding; and all other sectors reflect standard capital/labor substitution (with two types of labor: skilled and unskilled). There is a single representative household per modeled region, allocating income to consumption using the extended linear expenditure system. Trade is modeled using a nested Armington structure in which aggregate import demand is the outcome of allocating domestic absorption between 
domestic goods and aggregate imports, and then aggregate import demand is allocated across source countries to determine the bilateral trade flows.

There are several sources of protection in the model. The most important involves bilateral import tariffs. There are also bilateral export subsidies. Domestically, for numerous countries subsidies are important in agriculture, where they apply to intermediate goods, outputs, and payments to capital and land.

Three closure rules are used. First, government fiscal balances are fixed in any given year. ${ }^{4}$ The fiscal objective is met by changing the level of lump sum taxes on households. This implies that losses of tariff revenues are replaced by higher direct taxes on households. Second, the current account balance is fixed. Given that other external financial flows are fixed, this implies that ex ante changes to the trade balance are reflected in ex post changes to the real exchange rate. For example, if import tariffs are reduced, the propensity to import increases and additional imports are financed by increasing export revenues. The latter typically is achieved by a real exchange rate depreciation. Finally, investment is driven by savings. With fixed public and foreign saving, investment comes from changes in the savings behavior of households and from changes in the unit cost of investment. The latter can play an important role in a dynamic model if imported capital goods are taxed. Because the capital account is exogenous, rates of return across countries can differ over time and across simulations. The model only solves for relative prices, with the numéraire, or price anchor, being the export price index of manufactured exports

\footnotetext{
$4 \quad$ For the sake of simplicity they are fixed in US\$ terms at their base year level, minimizing potential sustainability problems; but this implies they decrease over time as a percentage of GDP for expanding economies.
} 
from high-income countries. This price is fixed at unity in the base year and throughout the projection period to 2015.

The version of the LINKAGE model used for this study is based on the GTAP database and is solved with 27 regions and 25 sectors. There is a heavy emphasis on agriculture and food, comprising 13 of the 25 sectors, and a focus on the largest commodity exporters and importers.

\section{Effects of current protection policies}

The LINKAGE model provides a baseline projection of the world economy first to 2005 and then to 2015 assuming no other policy changes. Deviations from that baseline in 2015, due to total liberalization from 2005, are then examined. The first step requires a pre-simulation to bring the world as depicted in the GTAP dataset in 2001 up to the start of 2005. In terms of policy shocks, we include only key multilateral commitments in that pre-simulation, namely the final stages of Uruguay Round implementation including the phase-out of the Multifibre Arrangement (MFA), the accession of China and Taiwan to the WTO, and the eastern enlargement of the European Union from 15 to 25 members. The impacts of those three reforms are non-trivial: had they not been implemented, the dynamic gains in 2015 from freeing global merchandise trade would have been an extra $\$ 64$ billion per year. Nearly half of that difference is due to the removal of MFA quotas and hence should be considered part of the Uruguay Round's legacy. The effect of those reforms on tariffs can be seen by comparing the estimates at the start of 2005 in Table 2 with those for 2001 in Table 1.

The next step is to measure the prospective effects of removing all agricultural subsidies plus those tariffs summarized in Table 2 over the 2005-2010 period. This could be done for each 
economy in turn, so as to assess the impact of own-country policies as in Jensen, Robinson and Tarp (2002). But since each country's policies are there to some extent because of other countries' policies, and are more likely to be reformed if other regions were to do so at the same time (as following a multilateral trade negotiation such as the Doha Agenda), a perhaps moreappropriate question is how each region's welfare, agricultural markets and farm incomes would change if all trade distortions were to be removed together. Our LINKAGE model's answer to that question is that it would lead to global gains by 2015 of $\$ 287$ billion per year. The distribution across regions of that economic welfare (or equivalent variation in income) gain, reported in Table 3, suggests two-thirds would accrue to high-income countries. However, as a share of national income, developing countries would gain more, with an average increase of 0.8 percent compared with 0.6 percent for high-income countries. The results vary widely across developing countries, ranging from little impact in the case of Bangladesh and Mexico to 4 or 5 percent increases in parts of East Asia.

The second column of numbers in Table 3 shows the amount of that welfare gain due to changes in the international terms of trade for each country. For developing countries as a group the terms of trade effect is negative, reducing somewhat the gains from improved efficiency of domestic resource use (especially in China and India). When the terms of trade effect is netted out, it generates the numbers in parentheses in the final column of Table 3 which can be interpreted as an indication of the relative degree of inter-sectoral distortion in each economy. By that indicator, developing countries are more than twice as wasteful of their resources as are high-income countries - and low-income countries are nearly three times as wasteful.

There are several ways to decompose the real income gains from full global trade reform so as to better understand the sources of the waste for each region. One way is to assess the 
impacts of developing country liberalization versus industrial country liberalization in different economic sectors; another is to decompose by policy instrument. The latter gives results very similar to those reported in Hertel and Keeney (2005), who estimate that market access barriers explain 93 percent of the welfare effects of agricultural policies, with domestic support and export subsidy removal contributing only 5 and 2 percentage points, respectively. ${ }^{5}$

Our results when decomposed by sector are provided in Table 4. They suggest global liberalization of agriculture and food markets contributes 63 percent of the total global gains (similar to Hertel and Keeney's 66 per cent). This is consistent with the high tariffs in agriculture and food versus other sectors shown in Table 1, but is nonetheless remarkable given the low shares of agriculture in global GDP (4 percent) and global merchandise trade (9 percent). Seventenths of those gains are accounted for by the farm policies of high-income countries, and those policies also account for the majority of the overall gains from trade reform to high-income countries. Notice also that developing country gains from high-income country reform are only half as large from textiles as from agricultural policies.

The full liberalization results suggest little change in the high-income countries' shares of global output and exports of processed food, beverages and tobacco. Only for primary agriculture are the changes noticeable: the export share falls by more than one-quarter, from 53 to 38 percent (including intra-EU trade) - but the output share falls by only one-sixth, from 30 to 25 percent (Table 5). For developing countries, their share of global output of food and agricultural products increases 2 percentage points and their share of global exports of those goods rises 4 percentage points. In absolute terms, agricultural and food output in high-income

\footnotetext{
5 Hoekman, Ng and Olarreago (2004) reach a similar conclusion from estimating the effects of halving each of the three types of agricultural distortions, in their case using partial equilibrium analysis.
} 
countries would decline but only by 0.1 percent per year over the projection period to 2015 following a move to free trade in all merchandise, instead of rising by 1.6 percent per year.

The impact of full trade reform on agricultural and food output and trade is shown for each country/region in Table 6, where it is clear that exports are enhanced much more than output. As a consequence, the global share of agricultural and food production exported rises, from 9.5 to 13.2 percent (or from 6.6 to 11.6 percent when intra-EU trade is excluded). The increase in exports of those goods from developing countries would be a huge \$191 billion per year more. Certainly Latin America accounts for a large part of that increase, but all regions' exports expand and even low-income countries would sell an extra \$36 billion worth of such goods per year (an increase of 52 percent). Also of interest is what happens to food imports: middle-income countries as a group would see them growing less rapidly than farm exports, while low-income countries' imports of those goods would grow only as fast as their exports of food and agricultural products, leaving their food and agricultural self sufficiency ratio unchanged. Even for high-income countries that ratio would fall only two percentage points, although it is concentrated in primary agricultural products where the fall is seven points. The opposite is true in Sub-Saharan Africa and Latin America, while for South Asia and China their agricultural self sufficiency levels would fall only one percentage point despite their expansion in exports of labor-intensive manufactures (Table 7).

Would freeing global merchandise trade lead to more trade gain for developing countries than for high-income countries, given the latter's high protection rates in agriculture and textiles? This question is pertinent for trade negotiators, who often think more in terms of the boost to the value of trade than to changes in economic welfare. Table 8 suggests any imbalance of that sort is not likely to be a major problem, even with complete trade liberalization. Certainly in those 
two protected sectors exports would increase more for developing than for high-income countries, but for other manufactures the trade growth for the two regions would have the opposite bias. Also, much of the developing countries' trade growth is with other developing countries. Hence for merchandise trade as a whole, developing countries would sell an extra \$318 billion to high-income countries under free trade whereas high-income countries would sell an extra $\$ 290$ billion to developing countries. A small amount of services trade liberalization by developing countries would be sufficient to close that gap, if full reciprocity were sought.

How big would be the consequences of reform for farm output and employment growth over the implementation period post-2004? Table 9 shows what that annual growth to 2015 would be in the baseline (no policy changes post-2004) and what it would be if all distortions to merchandise trade were removed. If there were completely free trade, farm output would decline (instead of growing slightly) in just the EU and Japan while growing slower in a few other highly protective countries - but, for most countries/regions shown in Table 9, farming activities would expand. This contrasts with the rhetoric suggesting farm protection cuts would cause a major collapse of protected sectors.

The farm employment picture is somewhat different. Typically, economic growth leads to declines in not only the relative importance of agriculture (for reasons explained in Anderson 1987 and Martin and Warr 1993) but also in absolute numbers employed in farming once a country reaches middle-income status. Thus it is not surprising that numerous middle- and highincome countries are projected to lose farm jobs over the next decade in the baseline scenario of Table 9. For the most protected farm sectors, that rate of farm employment decline would more than double if the world were to move to completely free trade. For other economies, though, 
farm employment would grow a little faster, allowing developing countries to absorb more workers on their farms.

Such reform also raises the share of agricultural and food production that is exported globally, from 9.5 percent in the baseline to 13.2 percent under free merchandise trade (Table 10). Even in the protected countries this ratio rises a little, because farm resources would move within the sector from import-competing to more-competitive farming activities.

The relatively small percentage changes in net national economic welfare hide the fact that redistributions of welfare among groups within each country following trade reform can be much larger. This is clear from the impacts on real rewards to labor, capital and land that are reported in Table 11 . The results also strongly support the expectation from trade theory that returns to unskilled labor rise substantially in developing countries, and by more than wages of skilled workers, which in turn rise more than earnings from produced capital. That is, full reform would be likely to improve equity and reduce poverty in developing countries, given that the vast majority of their poor earn their income as unskilled laborers (including as farmers). For highincome countries, again consistent with standard trade theory, skilled workers gain more than unskilled workers. Those European and Northeast Asian farmers renting agricultural land would benefit from a large fall in farm rental costs, more or less offsetting the fall in prices for their output, while earnings of landowners in those countries would lose. ${ }^{6}$

Those changes in factor rewards assume labor is mobile between sectors. In the most densely populated developing countries full liberalization would encourage more farm workers to take up now-more-rewarding work in labor-intensive manufacturing and service activities, so

6 Their loss is relative to the no-reform baseline, which ignores the fact that such farm landowners have long enjoyed protection-inflated returns, in some cases for several decades. 
value-added in agriculture would fall not only in economies where it has been highly protected (Europe, Northeast Asia and the US) but also in South Asia - whose trade policies have a slightly pro-agricultural bias according to the GTAP database, and which enjoys expanding market access abroad for those non-agricultural products in which the region has a strong comparative advantage. ${ }^{7}$ All other developing country regions would see a rise in net farm income though (as would the developed country Cairns Group members of Canada, Australia and New Zealand). That is true of China not only because it has already reduced much of its agricultural protection as part of its reforms associated with its accession to WTO at the end of 2001, but also because it faces extremely high tariff barriers in it export markets for farm products (Jean, Laborde and Martin 2005). And it is true in particular of the Sub-Saharan African region, even when southern Africa is separated out, despite the fact that there are numerous net food importing and preference-receiving exporting countries in that region (see Anderson, Martin and van der Mensbrugghe (2005a) for more details). Table 12 shows separately the contributions of high-income and developing countries' farm policy reforms to that outcome, from which it is clear that most of the effect comes from one or other of those reforms, with only a minor contribution to the residual from non-agricultural sectors. Those value added changes are due in considerable part to the changes in import and export prices for farm and other products, which are summarized in Table 13.

Of particular importance to Brazil and some Sub-Saharan African countries is the case of cotton, which is receiving special attention in the WTO's Doha Development Agenda following the Cancun Trade Ministerial in 2003 and the Dispute Settlement case that went against the US

7 The move to free trade would boost South Asia's ratio of production to consumption in textiles and clothing from 1.51 to 1.66 , for example. 
in 2004. Under full trade and subsidy liberalization, global cotton markets would change dramatically: the value of production would fall by one-third or more than $\$ 5$ billion per year in high-income countries (mostly in the US), and the value of their exports would fall by $\$ 3.6$ billion. The world totals would hardly change though, as developing country output and exports of cotton would expand by about the same amounts, with Sub-Saharan Africa enjoying more of that gain than any other region (Table 14). Indeed cotton is so important in Sub-Saharan Africa minus South Africa that it contributes one-quarter of that region's net gain in agricultural value added from full liberalization. ${ }^{8}$

The bottom line, therefore, is that if all current distortions to world trade in merchandise were phased out over the rest of this decade then, according to the latest GTAP database and the Linkage model, by 2015 developing country agricultural production, employment and real net income would be greater than without such reform. And it would be greater in most regions within the developing country group, the exceptions being South Asia and Eastern Europe where import tariffs are higher for agricultural than non-agricultural goods. This does not necessarily mean that if each individual developing country were to unilaterally liberalize we would find farmers benefiting in all cases except in South Asia and Eastern Europe; but if we were to run those many individual model simulations we may well get that result also, since, as is apparent from Table 3, terms of trade effects of reforms by others are usually dominated by efficiency gains from own reforms except for the least-distorted economies.

8 If full cotton liberalization was included in the Doha package, it would nearly double both the net welfare gain and the boost in net farm income in the SSA region. Furthermore, the share of all developing countries in global cotton exports would be 85 percent instead of 56 percent in 2015 - all of which vindicates the efforts to ensure cotton receives specific and substantial attention in the Doha negotiations (see Anderson, Martin and van der Mensbrugghe 2005b). 
Finally, which commodities contribute most to the global cost of agricultural protection? That depends not only on the nominal rate of protection but also on the relative size of each subsector and the different degrees of responsiveness of inputs to changes in relative output prices. According to the Linkage model, rice, sugar and meat are the key contributors (Table 15). ${ }^{9}$ The first two of those especially are of importance to developing country farmers, so it is not surprising that their interest in agricultural trade reform is so intense.

\section{Lessons, implications and areas for further research}

The following are the key messages that emerge from our analysis:

- The potential gains from global trade reform are large, including for developing countries and especially when they participate in the reform, despite its adverse terms of trade impact on many developing countries;

- Agriculture is where the greatest gains from liberalization would occur;

- Liberalization would cause farm output and farm employment to be greater in developing countries relative to the baseline, except in South Asia;

- It is the poorest people that appear to be most likely to gain from global trade liberalization, namely farmers and unskilled laborers in developing countries; and, in particular,

9 Dairy's estimated contribution is much less despite the high rates of assistance to dairy farmers, presumably because the GTAP protection database relies just on tariffs and excludes the protective effect of non-tariff import barriers such as sanitary and phytosanitary restrictions, which may be much higher for fluid milk than for most other farm products. 
- Net farm income would be enhanced in all developing country regions other than South Asia (where job growth would be greater in non-farm activities).

To realize that potential gain, it is in agriculture that by far the largest cuts in bound tariffs and subsidies are required. The political sensitivity of farm support programs, coupled with the complexities of the measures introduced in the Uruguay Round Agreement on Agriculture and of the modalities set out in the Doha Framework Agreement of July 2004, make that a daunting task. However, with global gains of the order of $\$ 290$ billion per year at stake from removing trade barriers, even if no reforms were forthcoming in services, and even if the counterfactual is the status quo rather than protectionist backsliding, the political will needs to be found to bring about such reform. The WTO's Doha Development Agenda is an obvious vehicle for moving down this path (Anderson and Martin 2005a, b). Multilateral cuts in tariff bindings are especially helpful because they can lock in previous unilateral trade liberalizations that otherwise would remain unbound and hence vulnerable to reversals to higher protection; and they can be used as an opportunity to multilateralize previously agreed preferential trade agreements and thereby reduce the risk of trade diversion from those bilateral or regional arrangements. It remains to be seen whether the political will can be mustered to bring that Doha round to a successful conclusion.

The results concerning the extent of bias in trade policies against or in favor of agriculture are very much dependent on the levels of distortion in the GTAP database of course. Those for high-income countries are reasonably reliable, thanks in large part to the protection estimates provided by the OECD (2005 and earlier). Currently available estimates of (particularly agricultural) trade distortions and subsidies in developing countries are less reliable. Nor are many estimates provided in the GTAP database of export taxes or tax equivalents of 
quantitative restrictions and bans on exports. A new project at the World Bank is seeking to provide better estimates of that sort. Distortions to factor markets, particularly labor, may also have an important influence on the results for some countries if they were to be included in the model. More-challenging tasks would be to also provide estimates of distortions to services trade and foreign direct investment, so as to see what impact they also have on agricultural and other goods production and trade; and to estimate the poverty consequences of such reforms (building on pioneering empirical work in Hertel and Winters 2005). 


\section{References}

Anderson, K. (1987), ‘On Why Agriculture Declines With Economic Growth’, Agricultural Economics 1(3): 195-207, June.

Anderson, K. and W. Martin (eds.) (2005a), Agricultural Trade Reform and the Doha Development Agenda, New York: Palgrave Macmillan, co-published with the World Bank (forthcoming).

Anderson, K. and W. Martin (2005b), 'Agricultural Trade Reform and the Doha Development Agenda', The World Economy 28(9), September (forthcoming).

Anderson, K., W. Martin and D. van der Mensbrugghe (2005a), 'Would Multilateral Trade Reform Benefit Sub-Saharan Africa?” Policy Research Working Paper No. 3616, World Bank, Washington DC, June.

Anderson, K., W. Martin and D. van der Mensbrugghe (2005b), 'Doha Merchandise Trade Reform: What's at Stake for Developing Countries?’ Policy Research Working Paper No. xxxx, World Bank, Washington DC, August (forthcoming).

Bautista, R.M., S. Robinson, P.Wobst and F. Tarp (2001), 'Policy Bias and Agriculture: Partial and General Equilibrium Measures', Review of Development Economics 5(1): 89-104, February.

Bouët, A., Y. Decreux, L. Fontagné, S. Jean and D. Laborde (2004), 'A Consistent, ad valorem Equivalent Measure of Applied Protection Across the World: The MAcMap-HS6 Database', mimeo, CEPII, Paris, 20 December.

Crawford, J.-A. and R.V. Fiorentino (2005), 'The Changing landscape of Regional Trade Agreements’, Discussion paper No. 8, Geneva: World Trade Organization. 
Drabek, Z. and M. Bacchetta (2004), 'Tracing the Effects of WTO Accession on Policy-making in Sovereign States: Preliminary Lessons from the Recent Experience of Transition Countries', The World Economy 27: 1083-1125.

Jean, S., D. Laborde and W. Martin (2005), 'Consequences of Alternative Formulas for Agricultural Tariff Cuts', Ch 4 in Agricultural Trade Reform and the Doha Development Agenda, edited by K. Anderson and W. Martin, New York: Palgrave Macmillan (forthcoming).

Hertel, T. (ed.) (1997), Global Trade Analysis: Modeling and Applications, Cambridge and New York: Cambridge University Press.

Hertel, T.W. and R. Keeney (2005), 'What's at Stake: The Relative Importance of Import Barriers, Export Subsidies and Domestic Support', Ch. 2 in Agricultural Trade Reform and the Doha Development Agenda edited by K. Anderson and W. Martin, New York: Palgrave Macmillan (forthcoming).

Hertel, T.W. and L.A. Winters (eds.) (2005), Putting Development Back Into the Doha Agenda: Poverty Impacts of a WTO Agreement, New York: Palgrave Macmillan, co-published with the World Bank (forthcoming).

Hoekman, B., F. Ng and M. Olarreaga (2004), ‘Agricultural Tariffs versus Subsidies: What’s More Important for Developing Countries?’ World Bank Economic Review 18(2): 175204.

Jensen, H.T., S. Robinson and F. Tarp (2002), 'General Equilibrium Measures of Agricultural Policy Bias in Fifteen Developing Countries', TMD Discussion Paper No. 105, IFPRI, Washington DC, October. 
Krueger, A.O., M. Schiff and A. Valdes (1988), 'Agricultural Incentives in Developing Countries: Measuring the Effect of Sectoral and Economy-wide Policies', World Bank Economic Review 2(3): 255-72, September.

Legg, W. (2003), ‘Agricultural Subsidies: Measurement and Use in Policy Evaluation’, Journal of Agricultural Economics 54(2): 175-200, July.

Martin, W. and P.G. Warr (1993), 'Explaining the Relative Decline of Agriculture: A SupplySide Analysis for Indonesia', World Bank Economic Review 7(3): 381-401, September.

OECD (2005), Agricultural Policies in OECD Countries: Monitoring and Evaluation 2005, Paris: Organization for Economic Cooperation and Development.

Piermartini, R. (2004), 'The Role of Export Taxes in the Field of Primary Commodities', WTO Discussion Paper No. 4, Geneva.

Thiele, R. (2004), 'The Bias Against Agriculture in Sub-Saharan Africa: Has it Survived 20 Years of Structural Adjustment Programs?' Quarterly Journal of International Agriculture 42(1): 5-20.

Tyers, R. and K. Anderson (1992), Disarray in World Food Markets: A Quantitative Assessment, Cambridge and New York: Cambridge University Press.

van der Mensbrugghe, D. (2004), 'LinkAGE Technical Reference Document: Version 6.0’, mimeo, The World Bank, Washington, DC. Accessable at http://siteresources.worldbank.org/INTPROSPECTS/Resources/3349341100792545130/LinkageTechNote.pdf

World Bank (2002), Global Economic Prospects and the Developing Countries 2002: Making Trade Work for the Poor, Washington DC: The World Bank. 
World Bank (2004), Global Economic Prospects: Realizing the Development Promise of the Doha Agenda, Washington DC: The World Bank.

World Bank (2005), Global Economic Prospects: Trade, Regionalism, and Development, Washington DC: The World Bank. 
Table 1: Import-weighted average applied tariffs, by sector and region, 2001

(percent)

\begin{tabular}{|c|c|c|c|c|c|}
\hline Importing region: & $\begin{array}{r}\text { Agriculture } \\
\text { and } \\
\text { processed } \\
\text { food } \\
\end{array}$ & $\begin{array}{r}\text { Other } \\
\text { primary } \\
\text { products }^{\text {a }}\end{array}$ & $\begin{array}{r}\text { Textiles } \\
\text { and } \\
\text { clothing }\end{array}$ & $\begin{array}{r}\text { Other } \\
\text { manufact- } \\
\text { uring } \\
\end{array}$ & $\begin{array}{r}\text { ALL } \\
\text { GOODS }\end{array}$ \\
\hline High-income countries ${ }^{b}$ & 16.0 & 1.0 & 7.5 & 1.3 & 2.9 \\
\hline Developing countries & 17.7 & 6.5 & 17.0 & 8.3 & 9.9 \\
\hline Middle-income countries & 16.5 & 4.6 & 16.8 & 7.3 & 8.9 \\
\hline Low-income countries & 22.2 & 14.2 & 17.9 & 14.5 & 15.9 \\
\hline East Asia and Pacific & 26.3 & & 17.8 & 8.6 & 10.5 \\
\hline South Asia & 33.9 & & 20.1 & 22.2 & 23.5 \\
\hline Europe \& Central Asia & 14.8 & & 10.7 & 4.1 & 6.0 \\
\hline Middle East \& N. Africa & 14.1 & & 27.1 & 7.2 & 9.8 \\
\hline Sub-Saharan Africa & 18.2 & & 23.7 & 10.5 & 12.6 \\
\hline Latin America \& Carib. & 10.3 & 5.1 & 11.3 & 7.1 & 7.7 \\
\hline World total & 16.7 & & 10.2 & 3.5 & 5.2 \\
\hline
\end{tabular}

${ }^{a}$ Forestry, fishing, fuels, minerals and non-ferrous metals.

${ }^{b}$ Intra-EU15 trade is ignored in calculating weights for determining tariff averages.

Source: Authors’ compilations from the GTAP database Version 6.05 
Table 2: Import-weighted average applied tariffs, by sector and country, 2005 (percent)

\begin{tabular}{|c|c|c|c|c|c|}
\hline Importing region: & $\begin{array}{c}\text { Agriculture } \\
\text { and processed } \\
\text { food }\end{array}$ & $\begin{array}{c}\text { (Primary } \\
\text { agriculture } \\
\text { only) }\end{array}$ & $\begin{array}{l}\text { (Processed } \\
\text { food only) }\end{array}$ & $\begin{array}{c}\text { Textiles } \\
\text { and } \\
\text { clothing }\end{array}$ & $\begin{array}{c}\text { Other } \\
\text { manufac- } \\
\text { turing }\end{array}$ \\
\hline World & 15.2 & & & 9.3 & 3.1 \\
\hline High-income & 15.9 & & & 7.3 & 1.2 \\
\hline Australia \& NZ & 2.6 & 0.3 & 3.3 & 13.9 & 4.1 \\
\hline EU25 + EFTA & 13.9 & 13.2 & 14.7 & 5.1 & 1.7 \\
\hline United States & 2.4 & 2.3 & 2.5 & 9.6 & 0.9 \\
\hline Canada & 9.0 & 1.2 & 14.1 & 8.7 & 0.5 \\
\hline Japan & 29.3 & 48.0 & 20.8 & 9.0 & 0.4 \\
\hline S. Korea \& Taiwan & 53.0 & 84.5 & 22.4 & 9.2 & 3.6 \\
\hline Hong Kong \& Sing. & 0.1 & 0.0 & 0.2 & 0.0 & 0.0 \\
\hline Developing countries & 14.2 & & & 14.3 & 7.1 \\
\hline Middle-income & 12.1 & & & 13.6 & 6.0 \\
\hline Argentina & 7.1 & 5.6 & 7.8 & 11.1 & 10.1 \\
\hline Brazil & 5.0 & 2.4 & 9.0 & 14.7 & 9.7 \\
\hline China & 10.3 & 9.9 & 11.0 & 9.6 & 5.5 \\
\hline Mexico & 10.3 & 10.8 & 9.7 & 7.8 & 4.3 \\
\hline Russia & 13.5 & 14.6 & 12.8 & 15.8 & 7.8 \\
\hline South Africa & 8.6 & 5.9 & 10.6 & 21.9 & 5.4 \\
\hline Thailand & 16.7 & 12.7 & 19.2 & 16.4 & 7.6 \\
\hline Turkey & 16.6 & 16.4 & 17.0 & 3.8 & 1.2 \\
\hline Rest of East Asia & 13.4 & 18.6 & 9.0 & 8.7 & 3.5 \\
\hline Rest of LAC & 10.8 & 9.2 & 11.8 & 12.9 & 8.4 \\
\hline Rest of ECA & 15.7 & 10.4 & 19.5 & 9.3 & 3.2 \\
\hline M. East \&N. Africa & 13.1 & 8.2 & 18.3 & 23.9 & 7.2 \\
\hline Low-income & 22.0 & & & 17.9 & 14.1 \\
\hline Bangladesh & 12.7 & 7.4 & 21.2 & 29.9 & 16.2 \\
\hline India & 49.9 & 25.7 & 75.6 & 26.5 & 24.2 \\
\hline Indonesia & 5.0 & 4.3 & 6.2 & 8.0 & 4.3 \\
\hline Vietnam & 37.1 & 13.1 & 44.8 & 29.1 & 12.3 \\
\hline Rest of South Asia & 21.1 & 14.2 & 32.0 & 6.6 & 14.3 \\
\hline Selected SSAfrica ${ }^{\mathrm{a}}$ & 11.8 & 10.2 & 13.0 & 12.5 & 7.5 \\
\hline Rest of SSAfrica & 21.2 & 18.0 & 23.6 & 26.2 & 14.0 \\
\hline Rest of the World & 11.8 & 1.9 & 18.7 & 5.6 & 8.9 \\
\hline
\end{tabular}

${ }^{a}$ The Selected Sub-Saharan African countries (for which national modules are available in the LiNKAGE Model) include Botswana, Madagascar, Malawi, Mozambique, Tanzania, Uganda, Zambia, Zimbabwe.

${ }^{b}$ Numbers in parentheses are the averages at the start of 2005 following WTO accession by China and end of MFA.

Source: Authors' projections from the GTAP database Version 6.05 using the World Bank's LINKAGE model 
Table 3: Impacts on real income from full liberalization of global merchandise trade, by country/region, 2015

(relative to the baseline, in 2001 dollars and percent)

\begin{tabular}{|c|c|c|c|c|}
\hline & $\begin{array}{c}\text { Total real } \\
\text { income gain } \\
\text { p.a. } \\
\text { (\$billion) }\end{array}$ & $\begin{array}{c}\text { Change in } \\
\text { income due just } \\
\text { to change in } \\
\text { terms of trade } \\
\text { (\$billion) }\end{array}$ & $\begin{array}{c}\text { Gain due to } \\
\text { improved } \\
\text { efficiency of } \\
\text { resource use net } \\
\text { of terms of trade } \\
\text { effect } \\
\text { (\$billion) }\end{array}$ & $\begin{array}{l}\text { Total real gain } \\
\text { as percentage } \\
\text { of baseline } \\
\text { income in } 2015^{a}\end{array}$ \\
\hline Australia and New Zealand & 6.1 & 3.5 & 2.6 & $1.0(0.4)$ \\
\hline EU 25 plus EFTA & 65.2 & 0.5 & 64.7 & $0.6(0.6)$ \\
\hline United States & 16.2 & 10.7 & 6.5 & $0.1 \quad(0.0)$ \\
\hline Canada & 3.8 & -0.3 & 4.1 & $0.4 \quad(0.4)$ \\
\hline Japan & 54.6 & 7.5 & 47.1 & $1.1(1.0)$ \\
\hline Korea and Taiwan & 44.6 & 0.4 & 44.2 & 3.5 (3.5) \\
\hline Hong Kong and Singapore & 11.2 & 7.9 & 3.3 & $2.6(0.8)$ \\
\hline Argentina & 4.9 & 1.2 & 3.7 & $1.2(0.9)$ \\
\hline Bangladesh & 0.1 & -1.1 & 1.2 & $0.2(2.4)$ \\
\hline Brazil & 9.9 & 4.6 & 5.3 & $1.5(0.8)$ \\
\hline China & 5.6 & -8.3 & 13.9 & $0.2(0.5)$ \\
\hline India & 3.4 & -9.4 & 12.8 & $0.4 \quad(1.5)$ \\
\hline Indonesia & 1.9 & 0.2 & 1.7 & $0.7 \quad(0.7)$ \\
\hline Thailand & 7.7 & 0.7 & 7.0 & 3.8 (3.4) \\
\hline Vietnam & 3.0 & -0.2 & 3.2 & $5.2(5.5)$ \\
\hline Russia & 2.7 & -2.7 & 5.4 & $0.6(1.2)$ \\
\hline Mexico & 3.6 & -3.6 & 7.2 & $0.4 \quad(0.8)$ \\
\hline South Africa & 1.3 & 0.0 & 1.3 & $0.9(0.9)$ \\
\hline Turkey & 3.3 & 0.2 & 3.1 & $1.3(1.2)$ \\
\hline Rest of South Asia & 1.0 & -0.8 & 1.8 & $0.5 \quad(0.9)$ \\
\hline Rest of East Asia & 5.3 & -0.9 & 6.2 & $1.9(2.2)$ \\
\hline Rest of LAC & 10.3 & 0.0 & 10.3 & $1.2(1.2)$ \\
\hline Rest of ECA & 1.0 & -1.6 & 2.6 & $0.3(0.8)$ \\
\hline Middle East and North Africa & 14.0 & -6.4 & 20.4 & $1.2(1.7)$ \\
\hline Selected SSA countries & 1.0 & 0.5 & 0.5 & $1.5(0.8)$ \\
\hline Rest of Sub-Saharan Africa & 2.5 & -2.3 & 4.8 & 1.1 \\
\hline Rest of the World & 3.4 & 0.1 & 3.3 & $1.5(1.5)$ \\
\hline High-income countries & 201.6 & 30.3 & 171.3 & $0.6(0.5)$ \\
\hline Developing countries & 85.7 & -29.7 & 115.4 & $0.8(1.1)$ \\
\hline Middle-income countries & 69.5 & -16.7 & 86.2 & $0.8(1.0)$ \\
\hline Low-income countries & 16.2 & -12.9 & 29.1 & 0.8 (1.4) \\
\hline East Asia and Pacific & 23.5 & -8.5 & 32.0 & $0.7(1.0)$ \\
\hline South Asia & 4.5 & -11.2 & 15.7 & 0.4 \\
\hline Europe and Central Asia & 7.0 & -4.0 & 11.0 & $0.7 \quad(1.1)$ \\
\hline Sub-Saharan Africa & 4.8 & -1.8 & 6.6 & 1.1 (1.5) \\
\hline Latin America and the Carib & 28.7 & 2.2 & 26.5 & $1.0(0.9)$ \\
\hline World total & 287.3 & 0.6 & 286.7 & $0.7 \quad(0.7)$ \\
\hline
\end{tabular}

${ }^{a}$ Numbers in parentheses refer to that due to efficiency gains net of terms of trade effects. Source: Authors' World Bank LiNKAGE model simulations 
Table 4: Regional and sectoral source of gains from full liberalization of global merchandise trade, developing and high-income countries, 2015

(relative to the baseline scenario)

\begin{tabular}{|c|c|c|c|c|c|c|}
\hline & \multicolumn{3}{|c|}{ Gains by region in \$billion } & \multicolumn{3}{|c|}{ Percent of regional gain } \\
\hline & $\begin{array}{l}\text { Devel- } \\
\text { oping }\end{array}$ & $\begin{array}{l}\text { High- } \\
\text { income }\end{array}$ & World & $\begin{array}{l}\text { Devel- } \\
\text { oping }\end{array}$ & $\begin{array}{l}\text { High- } \\
\text { income }\end{array}$ & World \\
\hline \multicolumn{7}{|c|}{ Developing countries liberalize: } \\
\hline Agriculture and food & 28 & 19 & 47 & 33 & 9 & 17 \\
\hline Textiles and clothing & 9 & 14 & 23 & 10 & 7 & 8 \\
\hline Other merchandise & 6 & 52 & 58 & 7 & 26 & 20 \\
\hline All sectors & 43 & 85 & 128 & 50 & 42 & 45 \\
\hline \multicolumn{7}{|c|}{ High-income countries liberalize: } \\
\hline Agriculture and food & 26 & 109 & 135 & 30 & 54 & 47 \\
\hline Textiles and clothing & 13 & 2 & 15 & 15 & 1 & 5 \\
\hline Other merchandise & 4 & 5 & 9 & 5 & 3 & 3 \\
\hline All sectors & 43 & 116 & 159 & 50 & 58 & 55 \\
\hline \multicolumn{7}{|l|}{ All countries liberalize: } \\
\hline Agriculture and food & 54 & 128 & 182 & 63 & 63 & 63 \\
\hline Textiles and clothing & 22 & 16 & 38 & 25 & 8 & 14 \\
\hline Other merchandise & 10 & 57 & 67 & 12 & 29 & 23 \\
\hline All sectors & 86 & 201 & 287 & 100 & 100 & 100 \\
\hline
\end{tabular}

${ }^{a}$ Small interaction effects are distributed proportionately and numbers are rounded to sum to 100 percent

Source: Authors’ World Bank LiNKAGE model simulations 
Table 5: Developing countries' shares of global output and exports, by sector, 2015

(percent)

\begin{tabular}{lcccc}
\hline & $\begin{array}{c}\text { Primary } \\
\text { agriculture }\end{array}$ & $\begin{array}{c}\text { Processed food, } \\
\text { beverages and } \\
\text { tobacco }\end{array}$ & $\begin{array}{c}\text { Textiles and } \\
\text { clothing }\end{array}$ & $\begin{array}{c}\text { Other } \\
\text { manufacturing }\end{array}$ \\
\hline $\begin{array}{l}\text { Output } \\
\text { - baseline }\end{array}$ & 70 & & & \\
- free trade & 75 & 40 & 62 & 35 \\
Exports & & 40 & 65 & 35 \\
- baseline & 47 & & & 30 \\
- free trade & 62 & 34 & 63 & 32 \\
\hline
\end{tabular}

${ }^{a}$ Including intra-EU trade

Source: Authors’ World Bank LINKAGE model simulations 
Table 6: Impacts of full global trade liberalization on agricultural and food output and trade, by country/region, 2015

(relative to baseline)

\begin{tabular}{|c|c|c|c|c|c|c|}
\hline & \multicolumn{3}{|c|}{ \$billion } & \multicolumn{3}{|c|}{$\begin{array}{l}\text { Percent change relative to } \\
\text { baseline }\end{array}$} \\
\hline & Exports & Imports & Output & Exports & Imports & Output \\
\hline Australia and New Zealand & 18.0 & 1.4 & 27.9 & 38.0 & 23.0 & 20.5 \\
\hline EU 25 plus EFTA & 21.7 & 103.5 & -185.8 & -10.8 & 39.3 & -12.3 \\
\hline United States & 18.4 & 16.5 & 30.7 & 11.6 & 25.6 & 0.0 \\
\hline Canada & 14.6 & 6.9 & 7.2 & 40.2 & 54.3 & 4.8 \\
\hline Japan & 2.8 & 34.7 & -91.7 & 60.4 & 169.7 & -18.4 \\
\hline Korea and Taiwan & 33.2 & 12.3 & -0.4 & 600.2 & 189.8 & 20.2 \\
\hline Hong Kong and Singapore & 7.0 & 1.5 & 7.4 & 115.2 & 7.6 & 35.4 \\
\hline Argentina & 10.4 & 0.7 & 12.2 & 44.2 & 36.9 & 11.5 \\
\hline Bangladesh & 0.8 & 0.4 & -2.5 & 60.9 & 15.6 & 0.8 \\
\hline Brazil & 38.0 & 2.8 & 66.4 & 120.6 & 48.4 & 34.0 \\
\hline China & 15.1 & 24.1 & -9.9 & 145.6 & 27.3 & -0.9 \\
\hline India & 5.1 & 13.4 & -23.8 & 53.2 & 165.4 & -3.7 \\
\hline Indonesia & 3.6 & 1.9 & 4.5 & 32.2 & 23.5 & 2.4 \\
\hline Thailand & 5.6 & 5.2 & 5.3 & 29.2 & 57.2 & 4.7 \\
\hline Vietnam & 1.2 & 3.3 & -2.1 & 13.9 & 170.4 & -13.3 \\
\hline Russia & 0.7 & 4.4 & -7.8 & 15.4 & 22.3 & -5.4 \\
\hline Mexico & 11.9 & 6.7 & 6.2 & 66.0 & 52.9 & 2.2 \\
\hline South Africa & 2.4 & 1.1 & 1.4 & 55.9 & 40.2 & 4.9 \\
\hline Turkey & 4.3 & 4.3 & -0.1 & 109.4 & 140.3 & 0.5 \\
\hline Rest of South Asia & 2.9 & 3.7 & -1.5 & 57.1 & 83.3 & -1.8 \\
\hline Rest of East Asia & 9.4 & 5.8 & 7.4 & 61.7 & 50.7 & 6.8 \\
\hline Rest of LAC & 36.0 & 9.6 & 37.0 & 68.1 & 42.3 & 11.7 \\
\hline Rest of ECA & 9.2 & 10.9 & -22.2 & 106.0 & 90.5 & -1.6 \\
\hline Middle East and North Africa & 13.2 & 17.5 & -7.8 & 64.1 & 43.1 & -1.2 \\
\hline Selected SSA countries & 4.5 & 1.3 & 5.3 & 50.0 & 74.4 & 9.2 \\
\hline Rest of Sub Saharan Africa & 9.5 & 8.1 & -4.1 & 45.4 & 79.2 & -0.6 \\
\hline Rest of the World & 8.2 & 5.8 & 2.9 & 168.3 & 123.3 & 4.4 \\
\hline High-income countries & 115.8 & 176.7 & -204.7 & 15.7 & 65.5 & -5.3 \\
\hline Developing countries & 191.9 & 131.0 & 66.8 & 67.4 & 51.5 & 2.2 \\
\hline Middle-income countries & 156.1 & 93.1 & 88.2 & 72.7 & 41.9 & 3.2 \\
\hline Low-income countries & 35.8 & 37.9 & -21.4 & 52.3 & 99.3 & -1.0 \\
\hline East Asia and Pacific & 34.8 & 40.4 & 5.2 & 54.4 & 35.5 & 0.1 \\
\hline South Asia & 8.9 & 17.5 & -27.8 & 55.1 & 122.9 & -3.0 \\
\hline Europe and Central Asia & 14.2 & 19.6 & -30.0 & 79.7 & 62.6 & -1.9 \\
\hline Sub Saharan Africa & 16.4 & 10.5 & 2.6 & 47.7 & 71.6 & 2.1 \\
\hline Latin America and the Caribbean & 96.3 & 19.8 & 121.8 & 75.7 & 46.1 & 13.8 \\
\hline World total (excluding intra-European trade) & 307.7 & 307.7 & -137.8 & 36.3 & 59.8 & -1.3 \\
\hline
\end{tabular}

Source: Authors’ World Bank LiNKAGE model simulations 
Table 7: Impact of global liberalization on self sufficiency ${ }^{\mathrm{a}}$ in agricultural and other products, selected regions, 2015

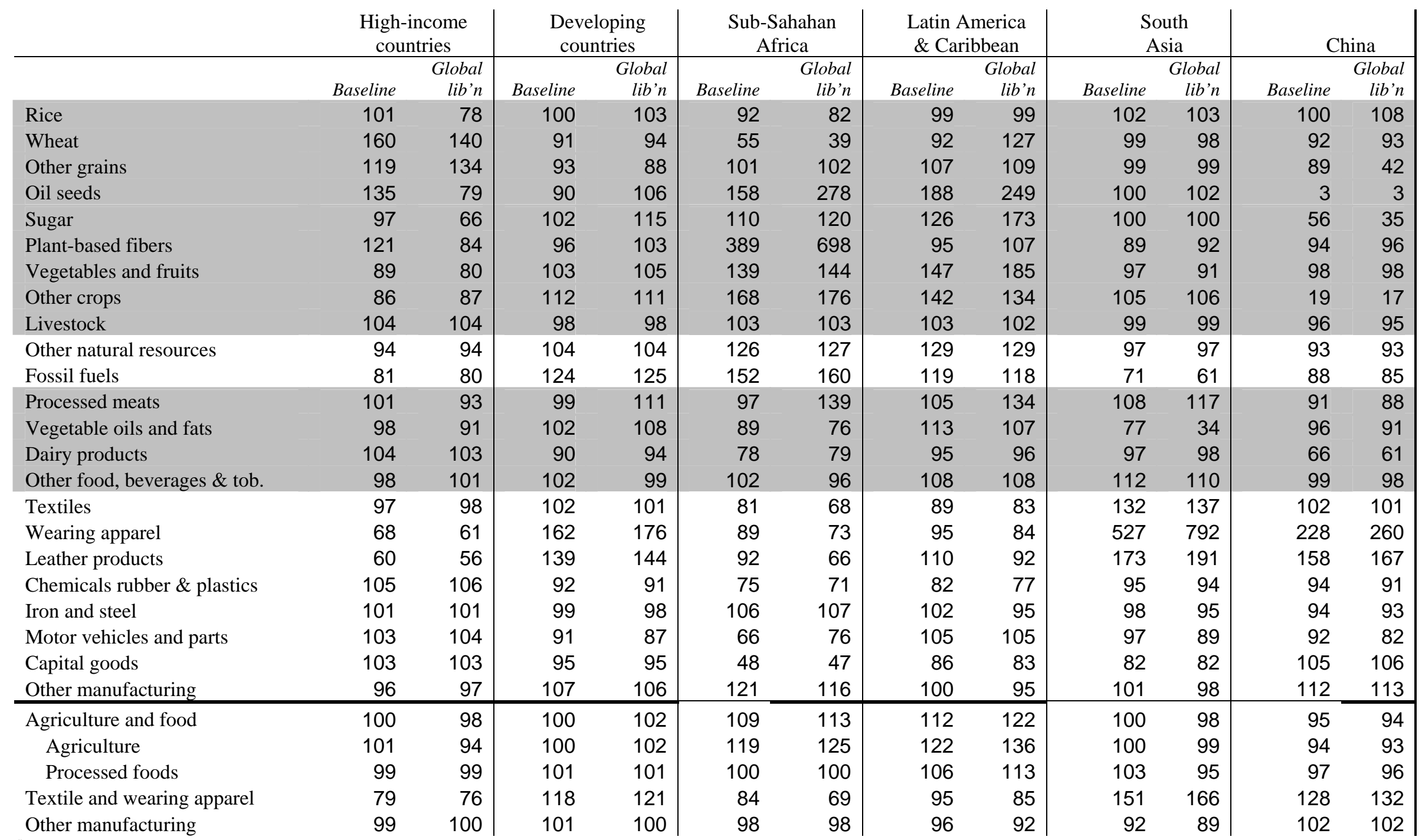

${ }^{a}$ Self sufficiency is defined as domestic production as a percentage of domestic consumption measured in value terms at fob prices.

Source: Authors’ World Bank LiNKAGE model simulations 
Table 8: Changes in bilateral trade flows from full global liberalization a ${ }^{\text {, }} 2015$

(Difference in bilateral trade flows at FOB prices in 2015 compared to the baseline, \$billion)

\begin{tabular}{|c|c|c|c|}
\hline & \multicolumn{3}{|c|}{ Importer: } \\
\hline & World & $\begin{array}{c}\text { High- } \\
\text { income } \\
\text { countries }\end{array}$ & $\begin{array}{c}\text { Developing } \\
\text { countries }\end{array}$ \\
\hline Exporter: & \multicolumn{3}{|c|}{ Agriculture and food } \\
\hline World & 314 & 186 & 128 \\
\hline High-income & 104 & 54 & 50 \\
\hline Developing & 210 & 133 & 77 \\
\hline \multicolumn{4}{|c|}{ Textiles and clothing } \\
\hline World & 164 & 79 & 85 \\
\hline High-income & 47 & 8 & 40 \\
\hline Developing & 117 & 71 & 46 \\
\hline \multicolumn{4}{|c|}{ Other manufacturing } \\
\hline World & 595 & 227 & 368 \\
\hline High-income & 312 & 112 & 200 \\
\hline Developing & 284 & 114 & 168 \\
\hline \multicolumn{4}{|c|}{ All merchandise trade } \\
\hline World & 1073 & 492 & 581 \\
\hline High-income & 463 & 174 & 290 \\
\hline Developing & 610 & 318 & 291 \\
\hline
\end{tabular}

${ }^{a}$ Aggregations exclude intra-EU trade

Source: Authors’ World Bank LiNKAGE model simulations 
Table 9: Agricultural output and employment growth, baseline and full liberalization, 2005-2015

(annual percent growth rate between 2005 and 2015)

\begin{tabular}{|c|c|c|c|c|}
\hline & \multicolumn{2}{|c|}{ Output growth } & \multicolumn{2}{|c|}{ Employment growth } \\
\hline & Baseline & $\begin{array}{l}\text { Full global } \\
\text { liberaliz'n }\end{array}$ & Baseline & $\begin{array}{l}\text { Full global } \\
\text { liberaliz'n }\end{array}$ \\
\hline Australia \& New Zealand & 3.5 & 5.2 & 0.4 & 1.9 \\
\hline EU 25 plus EFTA & 1.0 & -1.5 & -1.8 & -3.9 \\
\hline United States & 2.2 & 1.3 & -0.8 & -2.1 \\
\hline Canada & 3.5 & 5.2 & 0.2 & 1.9 \\
\hline Japan & 0.5 & -4.3 & -2.7 & -6.5 \\
\hline Korea and Taiwan & 2.2 & 0.1 & -1.3 & -3.9 \\
\hline Hong Kong and Singapore & 2.8 & 3.3 & 0.0 & 0.2 \\
\hline Argentina & 2.9 & 5.1 & 0.9 & 3.3 \\
\hline Bangladesh & 4.2 & 4.4 & 1.1 & 1.2 \\
\hline Brazil & 3.3 & 6.1 & 1.1 & 4.0 \\
\hline China & 4.3 & 4.3 & 0.8 & 0.7 \\
\hline India & 4.3 & 4.1 & 1.0 & 0.6 \\
\hline Indonesia & 3.0 & 2.9 & -0.7 & -0.7 \\
\hline Thailand & -0.1 & 1.3 & -4.6 & -3.7 \\
\hline Vietnam & 5.8 & 6.1 & 3.9 & 3.5 \\
\hline Russia & 1.5 & 1.0 & -2.3 & -2.7 \\
\hline Mexico & 3.9 & 4.1 & 2.0 & 2.3 \\
\hline South Africa & 2.5 & 3.3 & 0.0 & 0.8 \\
\hline Turkey & 3.0 & 2.6 & -0.5 & -1.2 \\
\hline Rest of South Asia & 4.8 & 4.8 & 2.0 & 1.9 \\
\hline Rest of East Asia & 3.7 & 3.5 & 0.2 & -0.1 \\
\hline Rest of LAC & 4.4 & 6.6 & 1.9 & 3.8 \\
\hline Rest of ECA & 3.3 & 3.3 & 0.0 & -0.1 \\
\hline Middle East \& N. Africa & 4.0 & 4.0 & 1.5 & 1.4 \\
\hline Selected SSA countries & 5.3 & 5.7 & 3.0 & 3.3 \\
\hline Rest of Sub-Saharan Africa & 4.6 & 4.8 & 2.2 & 2.5 \\
\hline Rest of the World & 5.0 & 6.4 & 2.4 & 3.5 \\
\hline High-income countries & 1.6 & -0.1 & -1.5 & -3.1 \\
\hline Developing countries (WB) & 3.9 & 4.2 & 1.0 & 1.2 \\
\hline Middle-income countries & 3.7 & 4.1 & 0.4 & 0.3 \\
\hline Low-income countries & 4.4 & 4.5 & 1.2 & 0.9 \\
\hline East Asia and Pacific & 4.0 & 4.0 & -0.5 & -0.8 \\
\hline South Asia & 4.4 & 4.2 & 1.5 & 1.4 \\
\hline Europe and Central Asia & 3.0 & 2.9 & 2.3 & 2.6 \\
\hline Middle East and N. Africa & 4.0 & 4.0 & 1.7 & 3.4 \\
\hline Sub-Saharan Africa & 4.5 & 4.9 & 0.2 & 0.0 \\
\hline Latin America and Carib. & 3.8 & 5.8 & 0.4 & 1.9 \\
\hline World total & 3.2 & 2.9 & -1.8 & -3.9 \\
\hline
\end{tabular}

Source: Authors’ World Bank LINKAGE model simulations 
Table 10: Share of agricultural and food production exported, 2001 and 2015

\begin{tabular}{|c|c|c|c|}
\hline & $\begin{array}{c}\text { Baseline } \\
2001\end{array}$ & Baseline & $\begin{array}{l}\text { Full global } \\
\text { liberaliz'n } \\
2015\end{array}$ \\
\hline Australia \& New Zealand & 33.3 & 37.2 & 42.7 \\
\hline EU 25 plus EFTA & 16.7 & 17.3 & 17.6 \\
\hline EU 25 plus EFTA (excl. intra-EU25) & 4.0 & 5.1 & 7.7 \\
\hline United States & 6.3 & 7.9 & 9.2 \\
\hline Canada & 24.5 & 29.5 & 40.0 \\
\hline Japan & 0.9 & 1.2 & 2.3 \\
\hline Korea and Taiwan & 4.4 & 4.8 & 26.5 \\
\hline Hong Kong and Singapore & 26.0 & 30.0 & 47.8 \\
\hline Argentina & 21.6 & 25.2 & 32.5 \\
\hline Bangladesh & 1.7 & 3.6 & 5.7 \\
\hline Brazil & 15.3 & 17.3 & 28.9 \\
\hline China & 3.3 & 0.9 & 2.2 \\
\hline India & 3.5 & 3.0 & 4.7 \\
\hline Indonesia & 11.9 & 10.0 & 12.9 \\
\hline Thailand & 30.2 & 28.2 & 34.6 \\
\hline Vietnam & 23.9 & 26.9 & 35.3 \\
\hline Russia & 6.1 & 5.5 & 6.7 \\
\hline Mexico & 5.6 & 7.8 & 13.2 \\
\hline South Africa & 16.0 & 12.7 & 18.8 \\
\hline Turkey & 9.6 & 6.0 & 12.4 \\
\hline Rest of South Asia & 6.0 & 6.2 & 9.9 \\
\hline Rest of East Asia & 16.1 & 14.6 & 22.1 \\
\hline Rest of LAC & 13.9 & 18.1 & 27.1 \\
\hline Rest of ECA & 2.4 & 1.7 & 3.7 \\
\hline Middle East \& N. Africa & 5.2 & 6.7 & 11.2 \\
\hline Selected SSA countries & 13.2 & 18.1 & 25.4 \\
\hline Rest of Sub-Saharan Africa & 11.2 & 15.8 & 23.3 \\
\hline Rest of the World & 6.6 & 7.0 & 17.7 \\
\hline High-income countries & 5.8 & 7.5 & 11.6 \\
\hline Developing countries & 7.5 & 6.9 & 11.6 \\
\hline Middle-income countries & 7.6 & 6.6 & 11.4 \\
\hline Low-income countries & 7.3 & 7.9 & 12.4 \\
\hline East Asia and Pacific & 7.2 & 4.1 & 6.5 \\
\hline South Asia & 3.8 & 3.6 & 5.7 \\
\hline Europe and Central Asia & 3.7 & 2.7 & 5.0 \\
\hline Sub-Saharan Africa & 12.5 & 15.8 & 23.1 \\
\hline Latin America \& the Caribbean & 12.7 & 15.9 & 24.8 \\
\hline World total & 9.5 & 9.5 & 13.2 \\
\hline World total (excl. intra-EU25) & 6.6 & 7.2 & 11.6 \\
\hline
\end{tabular}

Source: Authors’ World Bank LINKAGE model simulations 
Table 11: Impacts of full global merchandise trade liberalization on real factor prices, $2015^{\mathrm{a}}$

(relative to the baseline in 2015, percent)

\begin{tabular}{|c|c|c|c|c|c|}
\hline & $\begin{array}{c}\text { Un- } \\
\text { skilled } \\
\text { wages }\end{array}$ & $\begin{array}{c}\text { Skilled } \\
\text { wages }\end{array}$ & $\begin{array}{l}\text { Capital }^{b} \\
\text { user cost }\end{array}$ & $\begin{array}{c}\text { Land }^{\mathbf{b}} \\
\text { user cost }\end{array}$ & CPI \\
\hline Australia and New Zealand & 3.1 & 1.1 & -0.3 & 17.4 & 1.2 \\
\hline EU 25 plus EFTA & 0.0 & 1.3 & 0.7 & -45.4 & -1.3 \\
\hline United States & 0.1 & 0.3 & 0.0 & -11.0 & -0.4 \\
\hline Canada & 0.7 & 0.7 & 0.4 & 22.8 & -0.9 \\
\hline Japan & 1.3 & 2.2 & 1.1 & -67.4 & -0.1 \\
\hline Korea and Taiwan & 6.5 & 7.1 & 3.8 & -45.0 & -0.7 \\
\hline Hong Kong and Singapore & 3.2 & 1.6 & 0.3 & 4.4 & 1.1 \\
\hline Argentina & 2.9 & 0.5 & -0.7 & 21.3 & 0.3 \\
\hline Bangladesh & 1.8 & 1.7 & -0.2 & 1.8 & -7.2 \\
\hline Brazil & 2.7 & 1.4 & 1.6 & 32.4 & 2.2 \\
\hline China & 2.2 & 2.2 & 2.8 & -0.9 & -0.4 \\
\hline India & 2.8 & 4.6 & 1.8 & -2.6 & -6.0 \\
\hline Indonesia & 3.3 & 1.5 & 0.9 & 1.0 & 0.5 \\
\hline Thailand & 13.2 & 6.7 & 4.2 & 11.4 & -0.6 \\
\hline Vietnam & 25.3 & 17.6 & 11.0 & 6.8 & -2.3 \\
\hline Russia & 2.0 & 2.8 & 3.5 & -2.2 & -3.3 \\
\hline Mexico & 2.0 & 1.6 & 0.5 & 2.8 & -1.4 \\
\hline South Africa & 2.8 & 2.5 & 1.8 & 5.7 & -1.6 \\
\hline Turkey & 1.3 & 3.4 & 1.1 & -8.1 & -0.3 \\
\hline Rest of South Asia & 3.7 & 3.2 & 0.1 & 0.1 & -2.7 \\
\hline Rest of East Asia & 5.8 & 4.2 & 5.2 & -0.9 & -1.6 \\
\hline Rest of LAC & 5.7 & 1.4 & -0.4 & 17.8 & -1.2 \\
\hline Rest of ECA & 2.3 & 4.2 & 2.1 & -0.3 & -2.6 \\
\hline Middle East and North Africa & 4.1 & 4.1 & 2.6 & 2.4 & -3.1 \\
\hline Selected SSA countries & 6.0 & 1.6 & 0.0 & 4.6 & 0.4 \\
\hline Rest of Sub-Saharan Africa & 8.2 & 6.5 & 2.2 & 5.2 & -5.0 \\
\hline Rest of the World & 4.4 & 2.7 & 1.1 & 6.3 & -1.4 \\
\hline High-income countries & 0.6 & 1.1 & 0.5 & -20.0 & -0.6 \\
\hline Developing countries & 3.5 & 3.0 & 1.9 & 0.9 & -1.7 \\
\hline Middle-income countries & 3.2 & 2.6 & 1.9 & 2.2 & -1.1 \\
\hline Low-income countries & 4.2 & 3.9 & 1.9 & -1.0 & -4.0 \\
\hline World total & 1.2 & 1.5 & 0.8 & -0.8 & -0.8 \\
\hline
\end{tabular}

${ }^{a}$ Nominal factor prices deflated by the consumer price index (CPI).

${ }^{\mathrm{b}}$ The user cost of capital and land represents the subsidy inclusive rental cost.

Source: Authors’ World Bank LINKAGE model simulations 
Table 12: Effects of full liberalization of global agricultural and other merchandise trade on agricultural value added, by country/region, 2015

(relative to baseline, billion US dollars and percent)

\begin{tabular}{|c|c|c|c|c|c|c|}
\hline & $\begin{array}{r}\text { Developing } \\
\text { country } \\
\text { agr \& food } \\
\text { policies } \\
\end{array}$ & $\begin{array}{r}\text { \$billion } \\
\text { High- } \\
\text { income } \\
\text { country } \\
\text { agr\&food } \\
\text { policies } \\
\end{array}$ & $\begin{array}{r}\text { All goods } \\
\text { trade } \\
\text { policies } \\
\end{array}$ & $\begin{array}{r}\text { Developing } \\
\text { country } \\
\text { agr \& food } \\
\text { policies } \\
\end{array}$ & $\begin{array}{r}\text { percent } \\
\text { High- } \\
\text { income } \\
\text { country } \\
\text { agr \&food } \\
\text { policies } \\
\end{array}$ & $\begin{array}{r}\text { All goods } \\
\text { trade } \\
\text { policies }\end{array}$ \\
\hline Australia and New Zealand & 2.5 & 3.2 & 6.4 & 10.1 & 13.0 & 25.6 \\
\hline EU 25 plus EFTA & 7.3 & -42.0 & -39.1 & 4.9 & -28.3 & -26.4 \\
\hline United States & 5.1 & -20.7 & -18.2 & 4.2 & -17.0 & -15.0 \\
\hline Canada & 2.0 & 1.4 & 3.4 & 13.3 & 9.6 & 23.3 \\
\hline Japan & 0.2 & -17.7 & -17.7 & 0.4 & -39.6 & -39.5 \\
\hline Korea and Taiwan & 0.5 & -10.1 & -9.5 & 1.7 & -35.4 & -33.3 \\
\hline Hong Kong and Singapore & 0.1 & 0.1 & 0.1 & 3.6 & 5.0 & 7.5 \\
\hline Argentina & 0.4 & 4.9 & 6.1 & 2.1 & 27.4 & 33.8 \\
\hline Bangladesh & -0.4 & 0.2 & -0.5 & -3.3 & 1.7 & -4.4 \\
\hline Brazil & 0.0 & 15.1 & 15.1 & 0.1 & 46.2 & 46.3 \\
\hline China & -16.3 & 13.3 & 0.3 & -3.8 & 3.1 & 0.1 \\
\hline India & -17.3 & 2.9 & -17.1 & -8.2 & 1.4 & -8.1 \\
\hline Indonesia & -0.1 & 1.0 & 0.8 & -0.4 & 3.3 & 2.7 \\
\hline Thailand & 1.1 & 3.1 & 3.8 & 7.2 & 20.4 & 25.0 \\
\hline Vietnam & 0.9 & 0.3 & 0.8 & 14.5 & 5.7 & 13.6 \\
\hline Russia & -1.8 & 0.7 & -1.4 & -8.4 & 3.2 & -6.5 \\
\hline Mexico & -3.8 & 7.9 & 0.9 & -9.9 & 20.9 & 2.5 \\
\hline South Africa & 0.1 & 0.4 & 0.5 & 1.3 & 7.8 & 9.6 \\
\hline Turkey & -2.9 & 0.9 & -2.0 & -10.3 & 3.0 & -7.2 \\
\hline Rest of South Asia & -1.7 & 1.2 & -0.6 & -3.7 & 2.7 & -1.3 \\
\hline Rest of East Asia & -1.4 & 1.2 & -0.2 & -5.5 & 4.6 & -0.7 \\
\hline Rest of LAC & 1.9 & 19.7 & 22.9 & 2.5 & 26.0 & 30.2 \\
\hline Rest of ECA & -2.1 & 1.4 & -1.1 & -3.3 & 2.3 & -1.8 \\
\hline Middle East and North Africa & -4.8 & 6.2 & 0.3 & -4.4 & 5.6 & 0.3 \\
\hline Selected SSA countries & 0.4 & 1.1 & 1.5 & 2.7 & 6.5 & 9.1 \\
\hline Rest of Sub Saharan Africa & -0.7 & 3.0 & 2.3 & -1.7 & 7.2 & 5.4 \\
\hline Rest of the World & 0.7 & 2.5 & 3.1 & 3.4 & 13.2 & 16.4 \\
\hline High-income countries & 17.6 & -85.8 & -74.6 & 4.6 & -22.3 & -19.4 \\
\hline Developing countries & -47.9 & 87.1 & 35.6 & -3.9 & 7.0 & 2.9 \\
\hline Middle-income countries & -29.6 & 74.8 & 45.3 & -3.4 & 8.7 & 5.3 \\
\hline Low-income countries & -18.2 & 12.3 & -9.7 & -4.8 & 3.2 & -2.5 \\
\hline East Asia and Pacific & -15.8 & 18.9 & 5.5 & -3.2 & 3.8 & 1.1 \\
\hline South Asia & -19.4 & 4.4 & -18.1 & -7.2 & 1.6 & -6.8 \\
\hline Europe and Central Asia & -6.8 & 3.0 & -4.5 & -6.0 & 2.6 & -4.0 \\
\hline Middle East and North Africa & -4.8 & 6.2 & 0.3 & -4.4 & 5.6 & 0.3 \\
\hline Sub Saharan Africa & -0.2 & 4.5 & 4.3 & -0.3 & 7.1 & 6.7 \\
\hline Latin America and the Caribbean & -1.4 & 47.7 & 45.0 & -0.9 & 29.0 & 27.4 \\
\hline World total & -30.3 & 1.3 & -39.0 & -1.9 & 0.1 & -2.4 \\
\hline
\end{tabular}

Source: Authors' World Bank LINKAGE model simulations 
Table 13: Impact of full liberalization of global merchandise trade on indexes of real export and import prices

(Change in export and import price in 2015 relative to baseline, percent)

\begin{tabular}{|c|c|c|c|c|}
\hline & \multicolumn{2}{|c|}{ Export prices } & \multicolumn{2}{|c|}{ Import prices } \\
\hline & $\begin{array}{l}\text { Ag \& } \\
\text { food }\end{array}$ & $\begin{array}{r}\text { All } \\
\text { merchandise }\end{array}$ & $\begin{array}{r}\text { Ag \& } \\
\text { food }\end{array}$ & $\begin{array}{r}\text { All } \\
\text { merchandise } \\
\end{array}$ \\
\hline Australia and New Zealand & 4.5 & 2.2 & 2.0 & 0.1 \\
\hline EU 25 plus EFTA & 1.0 & -0.1 & -0.1 & -0.4 \\
\hline United States & 10.1 & 0.5 & 1.5 & -0.4 \\
\hline Canada & 2.4 & -0.3 & 3.4 & -0.2 \\
\hline Japan & -5.0 & 0.9 & 1.6 & 0.0 \\
\hline Korea and Taiwan & -14.9 & 0.8 & 5.0 & 0.2 \\
\hline Hong Kong and Singapore & 1.6 & 1.8 & 2.0 & 0.2 \\
\hline Argentina & 2.8 & 2.9 & 3.3 & 0.3 \\
\hline Bangladesh & -6.5 & -5.5 & 5.9 & 0.7 \\
\hline Brazil & 6.0 & 3.0 & 2.6 & -0.2 \\
\hline China & -0.2 & -0.3 & 7.4 & 1.0 \\
\hline India & -3.5 & -6.1 & 5.0 & 0.1 \\
\hline Indonesia & 1.8 & 0.5 & 8.0 & 1.3 \\
\hline Thailand & 2.5 & -0.2 & 1.4 & 0.1 \\
\hline Vietnam & 4.8 & -0.8 & 3.7 & 0.3 \\
\hline Russia & -2.7 & -1.9 & 4.8 & 0.2 \\
\hline Mexico & 1.7 & -1.5 & 8.3 & 0.3 \\
\hline South Africa & -0.6 & -0.1 & 1.6 & -0.3 \\
\hline Turkey & -0.5 & -0.4 & 9.0 & 0.0 \\
\hline Rest of South Asia & 0.2 & -2.1 & 3.8 & 0.1 \\
\hline Rest of East Asia & 0.3 & -0.1 & 3.6 & 0.6 \\
\hline Rest of LAC & 2.0 & -0.3 & 3.5 & 0.1 \\
\hline Rest of ECA & -2.6 & -2.5 & 1.8 & -0.8 \\
\hline Middle East and North Africa & -1.0 & -1.8 & 4.5 & 0.1 \\
\hline Selected SSA countries & 2.6 & 1.4 & 1.5 & -0.6 \\
\hline Rest of Sub Saharan Africa & -1.4 & -3.1 & 3.7 & -0.1 \\
\hline Rest of the World & 0.1 & -0.5 & -0.8 & -0.3 \\
\hline High-income countries & 3.2 & 0.3 & 0.9 & -0.3 \\
\hline Developing countries & 1.2 & -0.8 & 5.0 & 0.4 \\
\hline Middle-income countries & 1.7 & -0.6 & 5.2 & 0.4 \\
\hline Low-income countries & -0.1 & -2.2 & 4.1 & 0.3 \\
\hline East Asia and Pacific & 1.6 & -0.2 & 6.2 & 0.8 \\
\hline South Asia & -2.7 & -5.1 & 4.8 & 0.1 \\
\hline Europe and Central Asia & -2.2 & -1.8 & 4.2 & -0.3 \\
\hline Sub Saharan Africa & -0.4 & -1.5 & 3.0 & -0.2 \\
\hline Latin America and the Caribbean & 3.1 & 0.0 & 4.8 & 0.1 \\
\hline World total (excluding intra-European trade) & 3.9 & 0.1 & 3.1 & 0.0 \\
\hline
\end{tabular}

Source: Authors’ World Bank LINKAGE model simulations 
Table 14: Impact of full global liberalization on output, value added and exports of cotton, ${ }^{\text {a }}$ by region, 2015

(2001 \$ billion)

\begin{tabular}{|c|c|c|c|}
\hline & $\begin{array}{l}\text { Cotton } \\
\text { output }\end{array}$ & $\begin{array}{r}\text { Value added } \\
\text { in cotton } \\
\text { production } \\
\end{array}$ & $\begin{array}{r}\text { Cotton } \\
\text { exports }^{b}\end{array}$ \\
\hline United States & -4.7 & -2.8 & -3.5 \\
\hline EU 25 plus EFTA & -1.4 & -0.5 & -1.0 \\
\hline Other high-income & 1.0 & 0.4 & 0.9 \\
\hline Sub-Saharan Africa & 2.2 & 1.1 & 1.9 \\
\hline Latin America & 1.2 & 0.6 & 0.7 \\
\hline Other developing & 1.8 & 0.4 & 1.6 \\
\hline World total & 0.1 & -0.7 & 0.6 \\
\hline
\end{tabular}

${ }^{a}$ Actually all plant-based fibers, but cotton is more than 95 percent of that sector.

${ }^{b}$ Including intra-EU trade

Source: Authors’ World Bank LINKAGE model simulations 
Table 15: Shares of the global cost of agricultural and processed food protection attributable to specific products, 2015

$$
\text { (per cent) }
$$

Rice

Sugar

Meat products

Coarse grains

Oilseed products

Dairy products

Wheat

Other (including beverages and tobacco)

TOTAL 100

Source: Authors’ World Bank LINKAGE model simulations 